\title{
Hintasäännöstely, subventiot ja kuluttajan ylijäämä: Sovellutus maataloustuotteiden kysyntään ja tarjontaan
}

\author{
VESA KANNIAINEN \\ Helsingin yliopisto, kansantaloustieteen laitos \\ Aleksanterinkatu 7 \\ 00100 Helsinki 10
}

RAIJA VOLK

Päskytie, 04260 Kerava 6

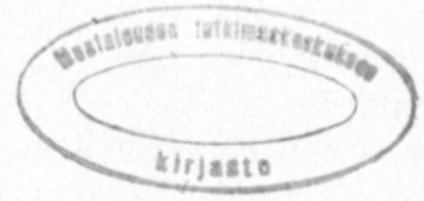

Price regulation, subsidies and consumer surplus: An application to the demand for and supply of agricultural products

\section{Vesa Kanniainen}

Department of Economics, University of Helsinki

Aleksanterinkatu 7, 00100 Helsinki 10

Raija Volk

Pääskytie, 0426 Kerava 6

\begin{abstract}
The target for self-sufficiency is one of the most important reasons for restrictions on imports of agricultural products. In the domestic market, this is often combined with subsidies and regulation of market prices. The paper studies the welfare and allocative implications of this kind of market intervention by the government. A fixed subsidy per unit of output produced is shown to be allocatively neutral in the sense that it will not change the optimal size of the production unit. However, the number of units will rise resulting in an increased market supply. In the case of a fixed lump-sum subsidy per production unit the allocative effects are greater. It is shown that the optimal size of production unit will decrease but the number of production units in the market will increase.
\end{abstract}




\section{Johdanto}

Kansantaloustiede on annettujen rajoitusten puitteissa tehtävien päätösten ja valintojen teoriaa. Eikä kansantaloustieteen käyttökelpoisuus suinkaan rajoitu pelkästään taloudellisiin valintoihin. Keskeiset kysymyksenasettelut talousteoriassa liittyvät yhtäältä niukkojen voimavarojen mahdollisimman tehokkaaseen kohdentumiseen ja toisaalta siihen, miten taloudellisen toiminnan tulokset jakautuvat eri tuotannontekijöiden kesken. Lisäksi on usein tärkeää tietää, tulisiko valtiovallan ja missä olosuhteissa puuttua mm. hintamekanismin rooliin voimavarojen kohdentumisessa ja minkälaisia hyvinvointivaikutuksia julkiseen "interventioon" tällöin liittyy.

Yllä sanotun perusteella on selvää, että myös maataloustuotanto muodostaa kokonaisuuden, jota on luontevaa lähestyä kansantaloustieteen näkökulmasta. Jos ajatellaan sellaisia allokaatio-ongelmia kuin työvoima- ja pääomaresurssien käyttöä, tuotannon kohdentumista eri tuotteiden ja tuotantosuuntien välille, investointeja maahan ja koneisiin tai hinnanmuodostusta ja suhteellisten hintojen määräytymistä, tarjoaa talousteoria hyödylliset välineet ko. ilmiöitä koskevien havaintojen organisoimiseksi ja ymmärtämiseksi. Käsillä olevan tutkielman rajattu tavoite on tämän näkökulman "markkinoiminen". Huomattakoon, että sen tekijät ovat koulutukseltaan kansantaloustieteilijöitä ilman minkäänlaisia maatalousekonomian opintoja. Näemme kuitenkin varsin toivottavana, että mm. USA:ssa agricultural economics -nimikkeellä tunnettu kansantaloustieteen sovelletusalue saisi Suomessakin jalansijaa nykyistä enemmän.

Niinpä käsityksemme on, että sellaisten politiikkavälineiden kuten tuontirajoitusten, hintasäännöstelyn ja tuotanto- ja pinta-alasubventioiden vaikutukset tuotantoon ja hintoihin tai vaikkapa inflaation, verotuksen ja poistosäädösten vaikutukset pääomakustannukseen ovat kysymyksiä, joiden ratkaisut yleisen kansantaloustieteen puolella ovat tunnettuja ja maatalousekonomiaan sovellettavissa. Käsillä olevassa tutkielmassa pyrimme hyödyntämään talousteoriaa maatalouspolitiikan analysointiin. Haluamme kuitenkin nähdä tutkielmamme pikemminkin alustavana ja virikkeiden lähteenä alan harrastajille kuin lopullisena sanana käsittelemistämme kysymyksistä. Tällä tavalla onkin tutkimuksemme tavoite nähtävä. Sen sijaan emme pyri ottamaan kantaa Suomessa harjoitettuun tai harjoitettavaan maatalouspolitiikkaan.

\section{Tuotannon ja hinnan määräytyminen vapaakaupan vallitessa: kaupan sulkemisen vaikutukset}

Olkoon jonkin hyödykkeen maailmanmarkkinakysyntä ja -tarjonta $\mathrm{D}_{\mathrm{w}}$ ja $\mathrm{S}_{\mathrm{w}}$ (kuva 1), jolloin tasapainohinta maailmanmarkkinoilla on $\mathrm{P}_{\mathrm{w}} \cdot{ }^{1} \mathrm{Nyt}$ pienelle avotaloudelle, olettaen että ulkomainen vaihtokurssi on 1, tarjonta on äärettömän joustavaa tällä hinnalla. Olkoon Suomen kysyntä D. Oletamme, että kotimainen tarjonta on sellainen, että Suomessa kansainvälisesti korkeiden tuotantokustannusten vuoksi tasapainohinta määräytyisi suurem- 
maksi kuin $\mathrm{P}_{\mathrm{W}}$. Niinpä efektiivinen kotimainen tarjonta onkin S:n asemesta $\mathrm{SP}_{\mathrm{W}}$ (kuva 2).

Siten kotimainen tuotanto olisi tasolla $\mathrm{q}_{1}$ ja tuonti ulkomailta $\mathrm{q}_{2}-\mathrm{q}_{1}$. Vapaakaupan vallitessa hinnat siten samaistuvat kansainvälisesti, kun oletetaan täydellinen hyödykearbitraasi ja jätetään siten $\mathrm{mm}$. kuljetuskustannukset huomioimatta.

Samalla teollisuustuotteiden ja maataloustuotteiden välinen hintasuhde muodostuu Suomessa samaksi kuin se on kansainvälisillä markkinoilla (ks. CAVES ja JONES 1977, luku 2).

Kuvatkoon TT transformaatiokäyrää maataloussektorin $(\mathrm{X})$ ja teollisuussektorin (Y) välillä (kuva 3). Olkoon suhteellinen hinta kotimaassa po vapaakaupan vallitessa ja $p_{1}$, jos maa ei käy kansainvälistä kauppaa lainkaan. Vapaakaupan tasapainoa kuvaa piste $\mathrm{E}_{0}$, joka merkitsee kansalaisille hyötytasoa $U_{0}$. $E_{0}$ määrittelee kulutuksen jakauman maatalous- ja teollisuustuotteiden kesken kotimaassa hintasuhteella po, joka määräytyy maailmanmarkkinoilla ja jonka ajatellaan maataloustuotteiden osalta vastaavan absoluuttista hintaa $\mathrm{P}_{\mathrm{W}}$. Vastaavasti piste A kuvaa tuotannon allokaatiota kotimaassa maataloustuotteiden ja teollisuustuotteiden kesken vapaakaupan vallitessa. Kaupan kolmio $\mathrm{E}_{0} \mathrm{AB}$ kertoo, että hintasuhteilla $\mathrm{p}_{0}$ maa tuo maataloustuotteita määrän $\mathrm{E}_{0} \mathrm{~B}\left(=\mathrm{q}_{2}-\mathrm{q}_{1}\right)$ ja vie teollisuustuotteita määrän $\mathrm{BA}$.

Tilanteessa, jossa kansainvälistä kauppaa ei sallita, hintasuhteet muuttuvat siten, että maataloustuotteiden absoluuttinen hinta nousee tasolle $P_{1}$ (kuva 2) ja suhteellinen hinta tasolle $\mathrm{p}_{1}$ (kuva 3 ). Kulutuspisteeksi tulee $\mathrm{E}_{1}$, joka on selvästi alemmalla hyötytasolla. Piste $\mathrm{E}_{1}$ kertoo myös kotimaisen tuotannon

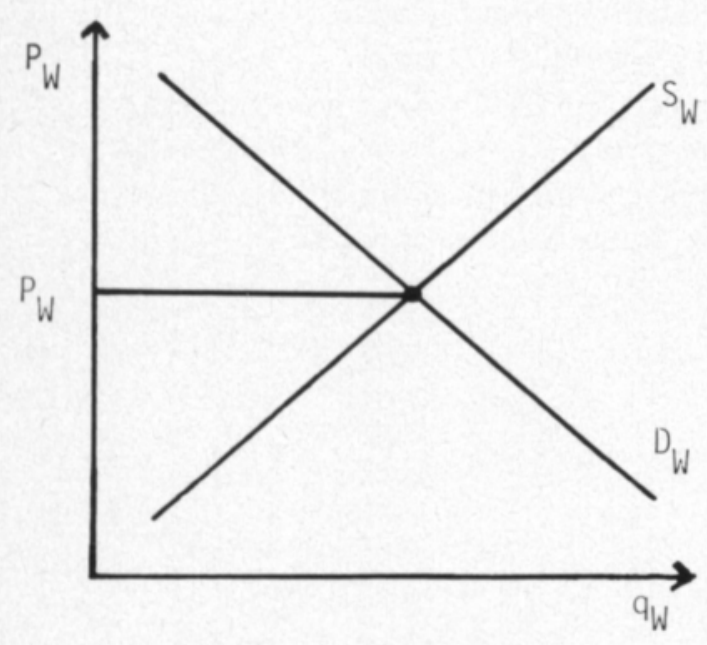

Kuva 1. Maailmanmarkkinahinta.

Fig. 1. Determination of the world price.

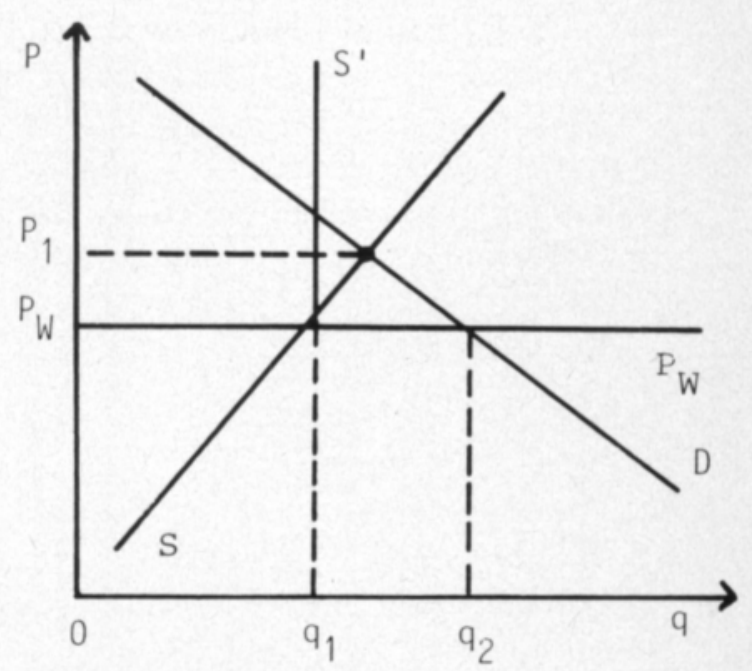

Kuva 2. Suomen hinta.

Fig. 2. Determination of the Finnish price.

1. Koska maataloussektori on lähes kaikkialla maailmassa säädelty ja suljettu, niin käsillä oleva tilanne kuvaa vain residuaalierien hinnanmuodostusta maailmanmarkkinoilla. Tämä määrää kuitenkin lyhyellä aikavälillä relevantin hinnan Suomen mahdollisen tuonnin näkökulmasta. 


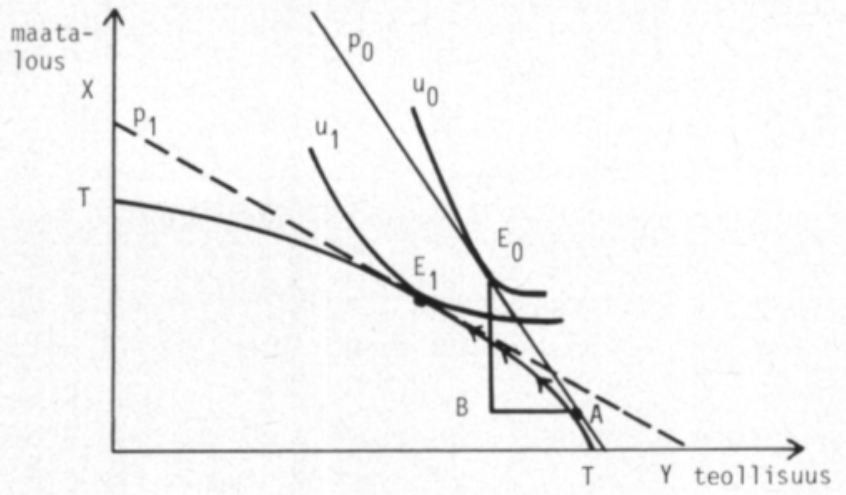

Kuva 3. Kaupan sulkemisen vaikutukset.

Fig. 3. The effects of closing the trade.

allokaation mainittujen kahden sektorin välillä. Maataloustuotteiden alhaisen tulojouston vuoksi suhteellisen hinnan muutoksesta aiheutuva tulovaikutus vähentää teollisuustuotteiden kulutusta suhteellisesti enemmän sïrryttäessä pisteestä $\mathrm{E}_{0}$ pisteeseen $\mathrm{E}_{1}$.

Resurssien uudelleensuuntaaminen pisteestä $A$ pisteeseen $E_{1}$ heijastuu siten hyvinvoinnin alenemisena kuluttajien keskuudessa. Samalla tapahtuu tulon uudelleenjakautumista maatalous- ja teollisuussektoreiden tuotannontekijöiden välillä. Seuraavassa kuviossa (kuva 4) pyritään arvioimaan kaupan sulkemisen hyvinvointivaikutuksia tuottajan ja kuluttajan ylijäämien avulla. Kuluttajan ylijäämän käytöstä hyvinvoinnin muutosten arvioimisessa viittaamme keskusteluun WILLIG (1976), McKENZIE (1979), WILLIG (1979). Todetaan ensiksikin, että tasapainohinta nousee $\mathrm{P}_{\mathrm{w}}$ :stä tasolle $\mathrm{P}_{1}$. Tällöin kuluttajien hyvinvointitappio on $\mathrm{B}+\mathrm{C}$. Tästä osa $\mathrm{B}$ on samanaikaisesti tuottajien ylijäämän kasvua, jolloin koko yhteiskunnan hyvinvointitappioksi jää alue C. Huomattakoon myös, että tuonnin loppuminen merkitsee sitä, että ulkomaiset tuottajat kokevat myös hyvinvointitappioita.

Yllä on todettu kaupan sulkemisen merkitsevän hyvinvointitappioita koko kansantalouden kannalta. Aleneehan hyötytaso $\mathrm{U}_{0}$ :sta $\mathrm{U}_{1}$ :een. Huomattakoon kuitenkin, että myönteisenä vaikutuksena on kansakunnan täydellinen omavaraisuus. Omavaraisuuden merkitys hyvinvoinnin kannalta on varsin

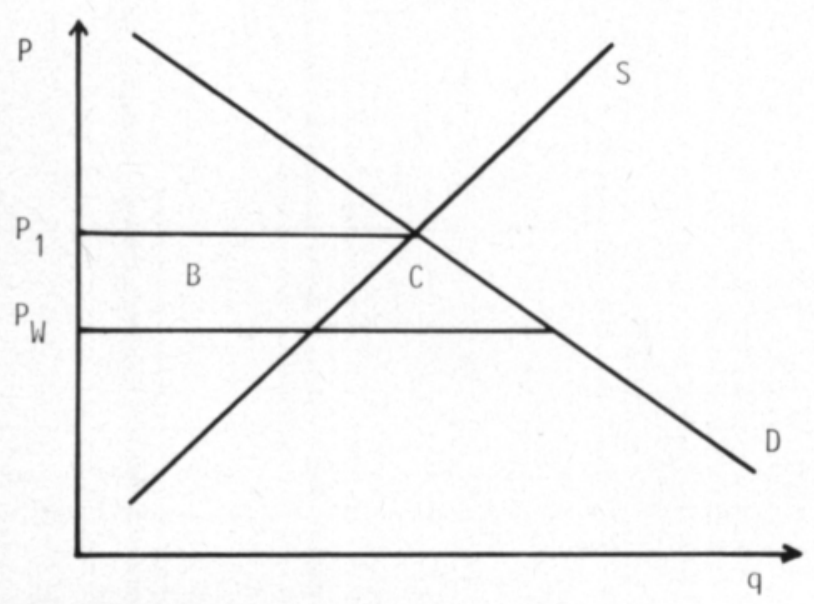

Kuva 4. Kaupan sulkemisen hyvinvointivaikutukset.

Fig. 4. Welfare effects of closing the trade. 
vaikeasti arvioitavissa oleva asia. Mitä suurempi on maataloustuotteiden saatavuus maailmanmarkkinoilla ja mitä suurempi niiden hinnan ennustettavuus, sitä pienempi paino omavaraisuudelle ilmeisesti on annettavissa.

Lisääntynyt epävarmuus maailmanmarkkinoilla samoin kuin maataloustuotteiden reaalisen maailmanmarkkinahinnan epävarma kehitys (sekä sen ennustettu kohoaminen 1980-luvulla) merkitsevät sitä, että omavaraisuudelle on annettava suurempi paino kuluvalla vuosikymmenellä kuin aikaisemmin. Tavallaan kysymys on intertemporaalisesta odotetun hyödyn maksimoinnista. Lisääntyvän omavaraisuuden nähdään pienentävän riskiä, joka aiheutuu siitä, että tuotteiden hinta ja mahdolliseti myös saatavuus maailmanmarkkinoilla heilahtelevat ja kulutuksesta saatu hyöty täten poikkeaa odotetusta hyödystä. Koska kuluttaja tyypillisesti on riskin välttäjä, hän on halukas hyväksymään varmuuden vallitessa pienemmän hyödykemäärän kuin odotettu hyödykemäärä epävarmuuden vallitessa olisi. Toisin sanoen, jos $\mathrm{Y}_{0}$ on varma hyödykemäärä markkinahintaan arvostettuna ja Y satunnaisesti vaihteleva hyödykemäärä, riskin välttäjä on valmis hyväksymään $Y_{0}: n$, joka on pienempi kuin epävarman kulutuksen odotusarvo E(Y) (PRATT (1964)). Erotus on tulkittavissa esimerkiksi vakuutusmaksuksi.

\section{Hintasäännöstelyn vaikutukset}

Edellä tarkasteltiin markkinahinnan määräytymistä puhtaasti kysynnän ja tarjonnan pohjalta yhtäältä vapaakaupan ja toisaalta suljetun talouden tilanteissa. Johtopäätöksenä oli, että kaupan esteiden vallitessa markkinahinta Suomessa muodostuu korkeista tuotantokustannuksista ja maailmanmarkkinoiden residuaaliluonteesta johtuen maailmanmarkkinahintaa korkeammaksi. Tämä aiheuttaa kuluttajille hyvinvointitappion, jonka kompensoimiseksi julkisen vallan oletetaan nyt suorittavan markkinahintojen säännöstelyä kotimaassa.

Oletetaan, että julkinen valta asetta tuotteille hintakaton (p), joka esimerkiksi voi olla lähellä maailmanmarkkinahintoja (kuva 5). Hintasäännöstely aiheuttaa sen, että tarjontakäyrän SS sijasta efektiivinen tarjonta noudattaa nyt käyrää SS': hinnalla $\bar{p}$ kokonaistuotanto ei voi olla suurempi kuin $\mathrm{q}_{1}$ ja se on pienempi kuin tuotanto tasapainotilanteessa eli $\mathrm{q}^{*}$.

Hintasäännöstelyn hyvinvointivaikutukset ovat seuraavat. Kuluttajan ylijäämä suurenee määrällä $\mathrm{A}$, mutta supistuu määrällä B. Edellinen johtuu siitä, että kuluttajat saavat tuotteet nyt halvemmalla, jälkimmäinen siitä, että osa kuluttajista jää nyt kokonaan ilman tuotteita. Itse asiassa hintasäännöstely synnyttää liikakysynnän, jonka suuruus on $\mathrm{q}_{2}-\mathrm{q}_{1}$. Hintasäännöstely alentaa tuottajien kannattavuutta ja johtaa tuottajien ylijäämän supistumiseen määrällä $\mathrm{A}+\mathrm{C}$. Huomattakoon, että $\mathrm{A}$ ei merkitse yhteiskunnallista kustannusta: se on tulonsiirto kahden väestöryhmän välillä (tuottajilta kuluttajille). Kolmiot B ja C sen sijaan ovat ne kuluttajien ja tuottajien hyvinvointitappiot, joita ei vastaa kenenkään hyvinvoinnin lisääntyminen. Tämä on siten hintasäännöstelystä aiheutuva nettotappio koko yhteiskunnalle. 


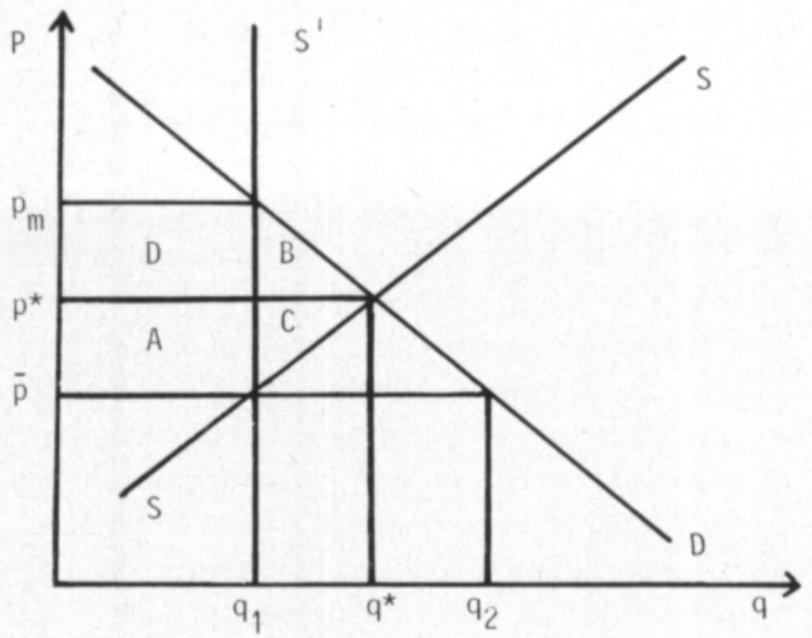

Kuva 5. Hintasän̈nöstelyn vaikutukset.

Fig. S. The effect of price regulation.

Kokemuksesta tiedämme, että kattohinnoilla on taipumus johtaa vähemmän tehokkaiden allokaatiomenetelmien syntyyn. Niinpä pysyvä liikakysyntä saattaisi johtaa siihen, että tuotteiden jakelu tapahtuisi "mustien markkinoiden" kautta kuten esim. sota-aikana tapahtuu. Edellä kuvattu malli ennustaa, että mustien markkinoiden tasapainohinnaksi muodostuisi $\mathrm{p}_{\mathrm{m}}$ : se on hinta, jonka kuluttajat olisivat valmiit maksamaan määrästä $\mathrm{q}_{1}$ ja se hinta säännöstelisi kaikki muut kysyjät pois markkinoilta. $\mathrm{p}_{\mathrm{m}}$ heijastaisi sitä marginaalihyötyä, jonka kuluttaja olisi valmis asettamaan viimeiselle tuotetulle yksikölle tuotannon ollessa tasolla $\mathrm{q}_{1}$. Tällöin kuluttajat häviäisivät kaiken sen, mitä he hyötyisivät hintasäännöstelystä ja sen mukanaan tuomista alhaisista hinnoista. Kuluttajan tappio olisi A+D ja se menisi tuottajille tai mustilla markkinoilla toimiville välittäjille. Säännöstelemättömään tilanteeseen verrattuna olisi kuluttajan hyvinvointimenestys $\mathrm{B}+\mathrm{D}$.

Johtopäätöksemme onkin, että pelkän hintasäännöstelyn toteuttaminen ei aikaansaa toivottuja hyvinvointivaikutuksia kuluttajan näkökulmasta. ${ }^{1} \mathrm{Hin}$ nan stabiloiminen tasolle, joka on alempi kuin $\mathrm{p}^{*}$, edellyttää jonkinlaista tuotannon subventiojärjestelmää. Niinpä lähes kaikissa maissa, Suomi mukaanlukien, on hintasäännöstelyyn yhdistetty jonkinlainen subventiopolitiikka. Analysoimme alla kahdentyyppistä subventiojärjestelmää. Ensimmäisessä tuki suhteutetaan tuotosyksikköön, toisessa se lasketaan tuottajaa kohden.

\section{Tuotosyksikköä kohden lasketun subvention allokaatiovaikutukset}

Olkoon subvention suuruus tuotosyksikköä kohden s. Parametri s on siten julkisen vallan politiikkamuuttuja. Tuotannon kokonaiskustannukset ilman subventiota ovat (kuva 6):

\footnotetext{
${ }^{1}$ Hintastabiliteetti ja hinnan ennustettavuus pienentää kuluttajan riskiä ja voi sen vuoksi aiheuttaa myös hyvinvointivaikutuksia, joita edellä ei ole huomioitu.
} 
Kuva 6. Subvention vaikutus kokonaiskustannuksiin.

Fig. 6. The effect of subsidies on total costs.

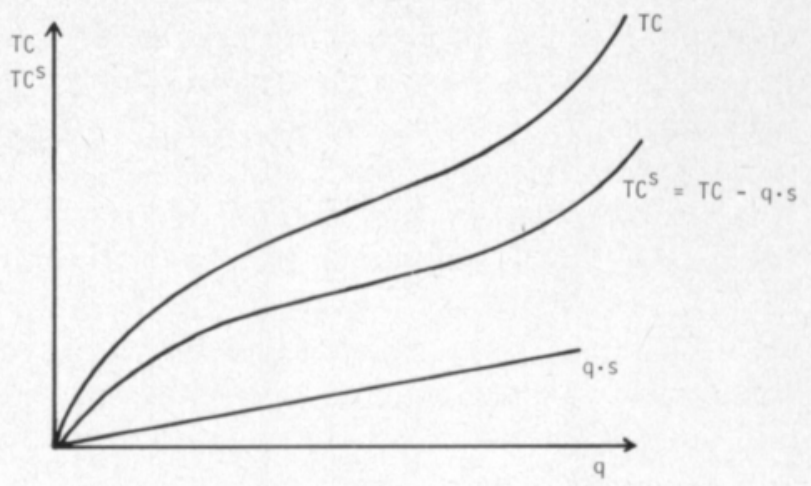

$$
\mathrm{TC}=\mathrm{qc}(\mathrm{q})
$$

subvention jälkeen

$$
\mathrm{TC}^{s}=\mathrm{q}(\mathrm{c}(\mathrm{q})-\mathrm{s}),
$$

jossa c(q) on tuotannon yksikkökustannus (keskimääräinen kustannus) ilman subventiota ja q tuotannon määrä. Oletamme, että c’(q) on aluksi negatiivinen, mutta muuttuu määrätyllä $\mathrm{q}: \mathrm{n}$ tasolla positiiviseksi. Toisin sanoen keskimääräisten kustannusten käyrä on U-muotoinen. Rajakustannusfunktio voidaan esittää seuraavasti:

$$
M C^{s}=q \cdot c^{\prime}(q)+c(q)-s .
$$

Kuvatulla subventiolla on siten se vaikutus, että se sïrtää sekä keskimääräis- että rajakustannuskäyrää vertikaalisessa suunnassa vakion s verran alaspäin (ks. kuva 7).

Huomattakoon, että kuvatulla subventiolla ei ole mitään vaikutusta keskimääräisten kustannusten minimipisteeseen. Siten subventio ei muuta tuotantoyrityksen optimaalista kokoa. Eri asia on, että markkinahinta vaikuttaa tarjottuun määrään: tarjontakäyrät siirtyvät oikealle, joten myös markkina-

Kuva 7. Subvention vaikutus rajakustannuksiin.

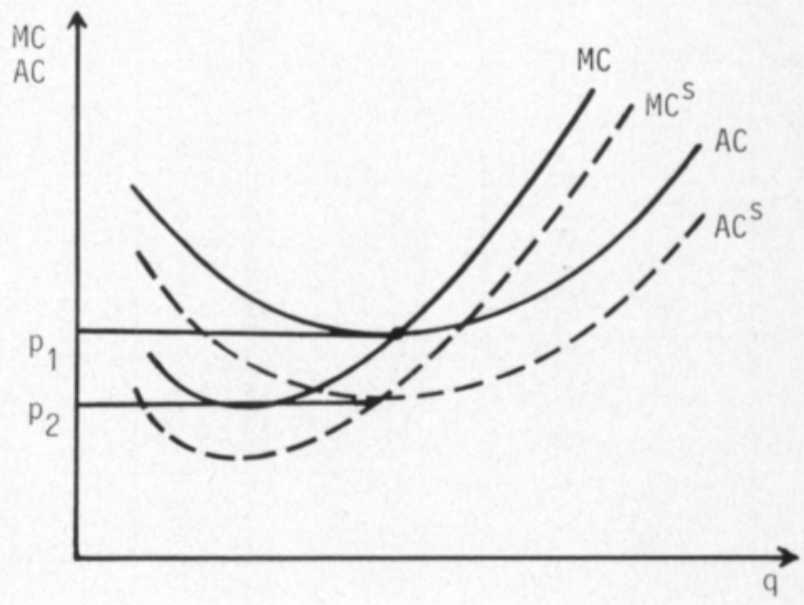


tarjonta lisääntyy. Kilpailevilla markkinoilla pitkän aikavälin tasapainohinta on $\mathrm{p}_{1}$. Subvention vaikutuksesta tuotantoyritysten lukumäärä lisääntyy (vaikka yksiköiden koko säilyy samana). Markkinatarjonta kasvaa kunnes tasapainohinta on alentunut tasolla $\mathrm{p}_{2}$.

Olisi sattuma, jos hintasäännöstely nyt johtaisi markkinahintaan, joka vastaisi AC-käyrän minimipistettä ja siten resurssien tehokkainta mahdollista allokaatiota. (Kuvassa 7 hintaan $\mathrm{p}_{1}$, jos keskimääräisten kustannusten käyrä on $\mathrm{AC}$ ja $\mathrm{p}_{2}$, jos kustannuskäyrä on $\mathrm{AC}$ ). Jos subventoidun tuotannon tapauksessa säännöstelty hinta asettuisi esimerkiksi $\mathrm{p}_{2}$ :n yläpuolelle, tämä olisi omiaan lisäämään kunkin tuotantoyksikön tarjontaa ohitse AC:n minimipisteen. Toisaalta subvention alentaessa koko AC käyrää tämä merkitsee vapaan markkinoille pääsyn vallitessa sitä, että tuotantoa harjoittavat myös sellaiset tuotantoyksiköt, jotka olisivat pois markkinoilta ilman tukea. Siten yhdistettyyn hintasäännöstely- ja subventiopolitiikkaan saattaa liittyä seuraavia allokaatiovaikutuksia. Ensiksi, vaikka tuotosyksikköä kohden laskettu subventio ei johda sinänsä yrityskoon eikä panossuhteen muuttumiseen, se lisää yritysten lukumäärää. Toiseksi, hintasäännöstely todennäköisesti muuttaa yritysten kokojakaumaa.

Koko markkinoiden kannalta keskeinen johtopäätös on nyt, että kuvatun subvention vaikutuksesta markkinatarjontakäyrä siirtyy oikealle, kun oletetaan, että panosten hinnat eivät reagoi ainakaan voimakkaasti kokonaistarjonnan muutoksiin. Tasapaino edellyttää, että tarjontakäyrä siirtyy asemaan $S^{s}$ kuvassa 8. S kuvaa alkuperäistä tarjontakäyrää ilman säännöstelyä (notional supply) ja SS' efektiivistä tarjontaa säännöstelyn vallitessa.

Tasapaino ennen subventiota (hintasäännöstelyn toteuduttua) oli $E_{0}$ ja subventiotasapaino on $\mathrm{E}_{1}$. Minkälaisia hyvinvointivaikutuksia kuvattuun subventiojärjestelmään liittyy niiden vaikutusten lisäksi, joita aikaisemmin tarkasteltiin?

Kuluttajan ylijäämä kasvaa määrällä $F+G$ ja tuottajien ylijäämä määrällä

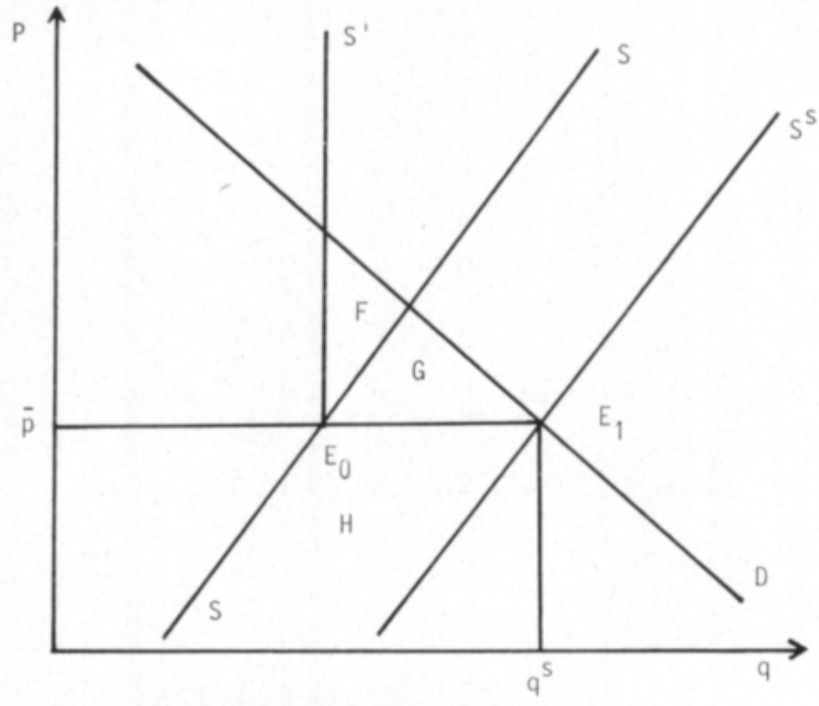

Kuva 8. Subvention vaikutus markkinatarjontaan.

Fig. 8. The effect of subsidies on the market supply. 
H. Edellinen perustuu siihen, että nyt kaikki kuluttajat saavat ilman säännöstelyä haluamansa määrän tuotteita. Kokonaishyvinvoinnin lisäys on nyt F + $\mathrm{G}+\mathrm{H}$. On selvää, että ilmaiseksi tämä ei tule, vaan se on rahoitettava. Maataloustuottajien kokonaistulo on subvention jälkeen $q^{s}(\bar{p}+s)$, josta $q^{s} s$ rahoitetaan julkisen vallan kautta. Tämä taas edellyttää verotuksen nostamista (sekä kuluttajan että tuottajien keskuudessa). Verotuksen kohtaanto aiheuttaa tietysti tulonjakovaikutuksia. Samaten verotus usein vääristää allokaatiota muissa sektoreissa ja siihen saattaa täten liittyä hyvinvointitappioita, jotka tulisi huomioida. Verotus ts. aiheuttaa ns. tulo- ja substituutiovaikutukset. Tulovaikutukset merkitsevät tulonsiirtoa valtiolle. Substituutiovaikutukset sen sijaan aiheuttavat niitä muutoksia taloudellisessa käyttäytymisessä, joita kutsutaan allokaatiovinoutumiksi.

Yhteenvetona tästä analyysistä voidaan todeta, että subventioilla on mahdollista ratkaista liikakysyntäongelma ja siten lisätä kuluttajien (samoin kuin tuottajien) hyvinvointia. Subventiot on kuitenkin kerättävä verovaroilla ja tämä aiheuttaa omat hyvinvointivaikutuksensa.

Suomessa on eräiden maataloustuotteiden osalta ylituotantoa. Täten kokonaistuotanto ylittää sen, mitkä kotimaiset kuluttajat ovat valmiit ostamaan vallitsevilla hinnoilla. Analyyttisesti tämä tarkoittaa sitä, että kuvassa 8 kokonaistarjontakäyrä sijaitsee $S^{s}$-käyrän oikealla puolella. Kysymyksessä on siten ylisubventointi. Allokatiivisessa mielessä tulisi siten subventioita vähentää siellä, missä on ylituotantoa ja siirtää sinne, missä omavaraisuusaste on kansantalouden kannalta liian alhainen.

Tuotosyksikköä kohden jaetun subvention hyvinvointivaikutukset ylisubventoinnin tapauksessa ovat suoraviivaiset. Kuluttajien ylijäämä ei muutu lainkaan kuvaan 8 verrattuna. Sen sijaan tuottajien ylijäämä kasvaa siinä suhteessa kuin tarjontakäyrä on siirtynyt oikealle. Samanaikaisesti valtion menot kasvavat suhteessa subvention määrään sekä sen aiheuttamaan tuottajien märän lisääntymiseen. Osaksi valtion menojen kasvu kompensoituu sillä, että ylituotannon vienti aikaansaa valtiolle tuloja. Nämä eivät kuitenkaan kokonaan voi kompensoida lisääntyneitä menoja, koska ylituotanto on markkinoitava maailmanmarkkinoilla, joilla esïntyy monia muita markkinoijia ja hinta on suhteellisen alhainen.

\section{Tuotantoyksikköä kohden lasketun subvention allokaatiovaikutukset}

Tässä kappaleessa tarkastelemme sellaista subventiojärjestelmää, jossa subventio $(=\mathrm{u})$ maksetaan määrätyn tuotantokapasiteetin omistavalle tuotantoyritykselle siten, että subvention suuruus on tuotannon määrästä rïppumaton. Tuen vaikutus kokonaiskustannusfunktioon on esitetty kuvassa 9. Kustannusfunktio siirtyy vertikaalisesti u:n verran alaspäin.

Kiinteitä kustannuksia on merkitty f:llä. Koska subventoidut kokonaiskustannukset ovat

$$
\mathrm{TC}^{u}=\mathrm{q} \cdot \mathrm{c}(\mathrm{q})-\mathrm{u}
$$


ovat rajakustannukset

$$
\mathrm{MC}^{\mathrm{u}}=\mathrm{qc}(\mathrm{q})+\mathrm{c}(\mathrm{q})
$$

eli tuella ei ole mitään vaikutusta kunkin tuottajan tarjontafunktioon. Kuitenkin se alentaa tuotantoyksikön optimaalista kokoa, sillä keskimääräiset kustannukset ovat nyt

(6)

$$
A C^{u}=c(q)-\frac{u}{q} .
$$

Keskimääräisten kustannusten minimi määräytyy nyt pisteessä

$$
\frac{\partial A C^{u}}{\partial q}=c^{\prime}(q)+\frac{u}{q^{2}}=0
$$

eli ehdosta

$$
q^{2} c^{\prime}(q)=-u \text {. }
$$

Kun rajakustannus on nouseva eli $c^{\prime}(q)>0$, yhtälö (8) sanoo sen, että mitä korkeampi on subventio u, sitä pienempi on tuotantoyksikön optimaalinen koko. Graafisesti optimaalisen koon muuttuminen (pisteestä A pisteeseen B) on esitetty kuvassa 10 .
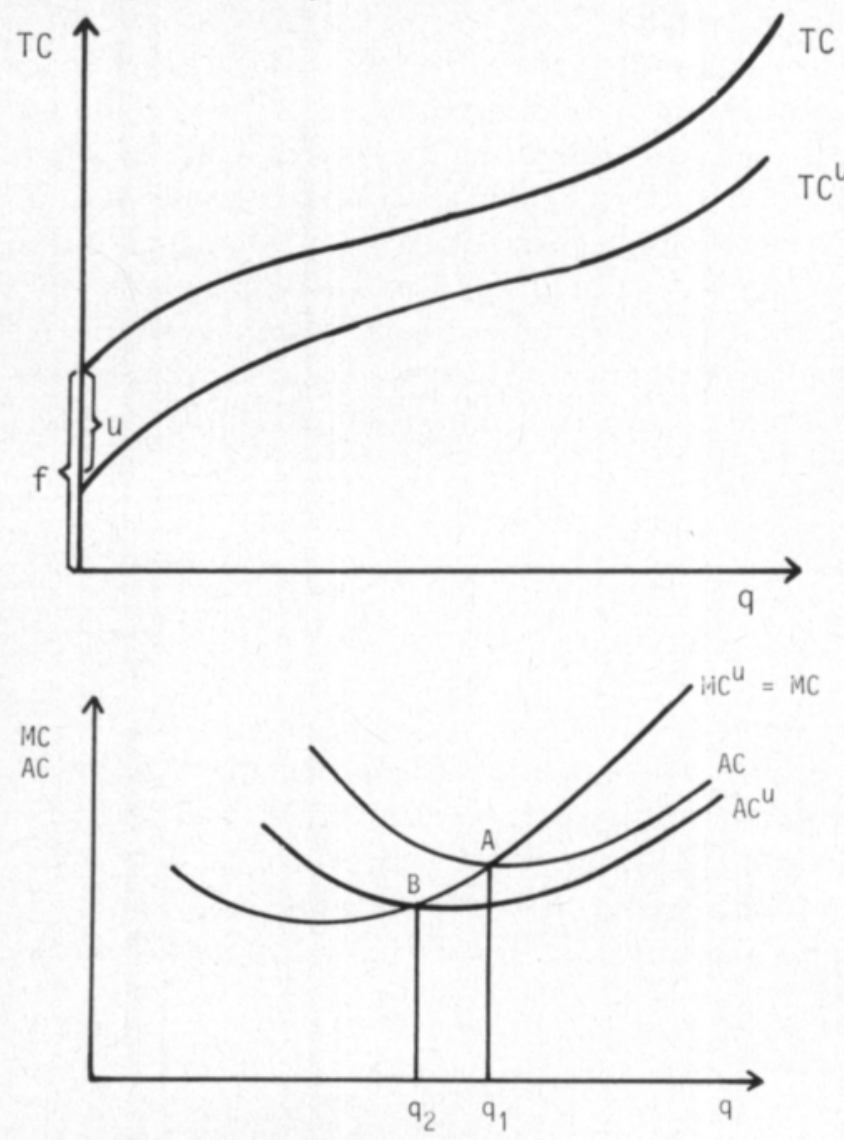

Kuva 9. Tuotosyksikköä kohden jaetun subvention vaikutus kokonaiskustannuksiin.

Fig. 9. The effect of a per unit subsidy on total costs.

Kuva 10. Subvention vaikutus tuotantoyksikön optimaaliseen kokoon.

Fig. 10. The effect of a subsidy on the optimal size of production unit. 
Siten ko. subventiolla ei ole lyhyellä aikavälillä tarjontaolosuhteita muuttavaa vaikutusta. Pitkällä aikavälillä se on omiaan alentamaan kunkin tuotantoyksikön optimaalisen kapasiteetin kokoa. Mutta subventiolla on toinenkin vaikutus. Koska $A C$-käyrän minimipiste alenee (A:sta $B$ :hen) tuen vaikutuksesta, tämä tekee tuotannon kannattavaksi hinnalla, joka on alhaisempi kuin tilanteessa, jossa ko. subventiota ei maksettaisi. Tämä on siten omiaan samalla lisäämään tuotantoyksiköiden lukumäärää, vaikka tuki alentaakin kunkin tuotantoyksikön optimikokoa, kuten yllä osoitettiin. Graafisesti tämä vaikutus on esitetty kuvassa 11.

Oletetaan markkinahinnan olevan $p_{0}$. Subvention vallitessa optimaalinen kapasiteetin ja tuotannon määrä on $\mathrm{q}_{0}$ kuvassa 11 , jolloin yrityksen kokonaistulo on $p_{0} q_{0}$. Sen vallitessa kokonaistuottojen $p_{0} q_{0}$ ja kokonaiskustannusten $\mathrm{TC}^{u}$ erotus on suurimmillaan eli z. Jos subventointia ei olisi, kokonaistuottojen ja kokonaiskustannusten erotus olisi kaikilla kapasiteetin ja tuotannon tasoilla negatiivinen. Tämä merkitsisi sitä, että sellaiset tuotantoyksiköt katoaisivat, joilla tuotantokustannukset ovat suhteellisen korkeita. Missä tuo kannattavuusraja kulkee, selvästi riippuu siitä, mille tasolle säännöstelty hinta $\mathrm{p}_{0}$ on asetettu.

Näillä johtopäätöksillä voidaan valaista sitä, miten merkittävästi erityyppiset julkisen vallan toimenpiteet vaikuttavat maataloustuotannon edellytyksiin, voimavarojen kohdentumiseen ja tuotannon tehokkuuteen. Tämä koskee niin valittua subvention muotoa kuin sitä tapaa, jolla hintasäännöstelyä harjoitetaan. ${ }^{1}$

Kuva 11. Subvention vaikutus tuotantoyksiköiden lukumäärään.

Fig. 11. The effect of a subsidy on the number of production units.

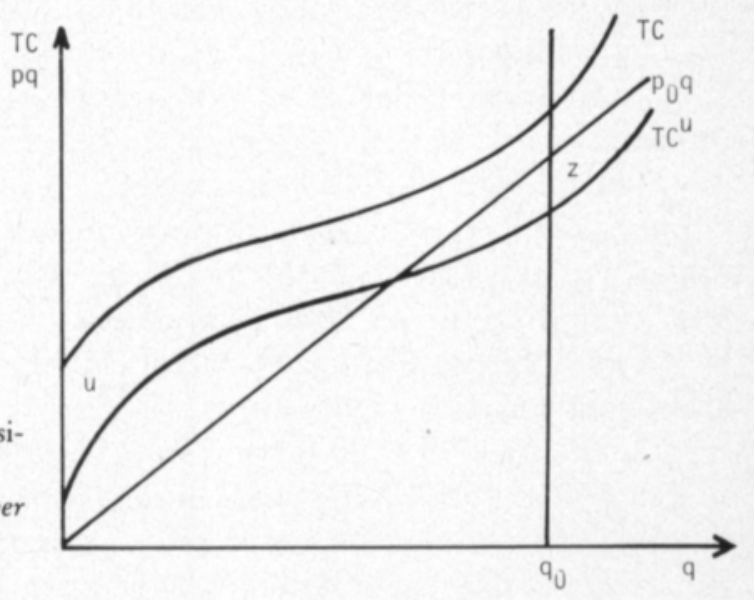

1. Tässä saadut tulokset heijastavat vain niitä yleisiä julkisen vallan rahoitusta käsittelevän kirjallisuuden periaatteita, joiden mukaan yleensä verot ja subventiot eivät ole allokatiivisessa mielessä neutraaleja. Johtopäätöksemme eivät täten ole mitenkään "uusia". Näkökulmaero julkisen vallan rahoitusta käsittelevään (public finance) kirjallisuuteen on siinä, että jälkimmäisessä usein mm. tarkastellaan, minkälainen vähennysjärjestelmä verotuksessa (poistot, korot ym.) takaa tuloveron neutraalisuuden. Tässä olemme analysoineet sellaisia subventiojärjestelmiä, jotka eivät vääristä tuotannontekijöiden hintasuhteita eivätkä siten vaikuta niiden käyttöä kuvaaviin marginaaliehtoihin, mutta jotka alentavat tuotannon kokonaiskustannuksia (vaihtoehtoisesti lisäävät kokonaistuottoja). Vaikka tuotantofunktiosta riippuen tuotannontekijöiden käyttösuhde saattaa myös muuttua, on analyysimme keskittynyt kysymykseen tuotantoyksikön pitkän aikavälin optimaalisesta koosta. 
Edellä on implisiittisesti oletettu, että markkinoilla olevat yritykset ovat kooltaan yhtä suuria. Jos markkinoilla on eri suuria yrityksiä, voivat joko suuret tai pienet yritykset joutua subvention jälkeen poistumaan markkinoilta riippuen siitä, miten yritysten keskimääräiskustannuskäyrät käyttäytyvät mentäessä ohi minimipisteen ja miten käyrät toisiinsa nähden sijaitsevat. Johtopäätökset kokonaistuotannon lisääntymisestä pitävät kuitenkin yhä paikkansa. Eroavaisuutta on siis vain sen suhteen, että eri kokoisten yritysten keskinäinen jakauma muuttuu.

Kuvatun subventiojärjestelmän hyvinvointivaikutukset ovat jossain määrin erilaiset kuin edellisessä tilanteessa, jossa subventio oli suhteutettu tuotannon määrään. Kuluttajien ylijäämä suurenee tässäkin tilanteessa kuten kuvassa 8: kuluttajat hyötyvät alhaisemmista markkinahinnoista. Samaten tuottajien ylijäämä suurenee. Merkittävin ero tulee vastaan siinä, että edellisessä subventiojärjestelmässä tuotantoyksikön optimaalinen koko ei muuttunut (joskin hintasäännöstely saattoi johtaa sielläkin tehottomaan allokaatioon). Jälkimmäisessä tapauksessa tuotantoyksikön optimikoko alenee ja lisääntynyt kysynnän määrä tyydytetään tuotantoyksiköiden lukumäärän kasvulla.

\section{Tiivistelmä}

Edellä on analysoitu hintasäännöstelyn ja muiden julkisen vallan toimenpiteiden vaikutuksia maataloustuotannon kannalta. Pyrkimys kansalliseen omavaraisuuteen sekä halu pitää kuluttajahinnat sen tasapainohinnan alapuolella, johon markkinahinnat johtaisivat, on nähty markkinamekanismiin puuttumisen syinä. Tähän ehkä voisi liittää hintastabiliteettitavoitteen. Varsin mielenkiintoinen on tällöin kysymys siitä, minkälaisia allokaatio- ja hyvinvointivaikutuksia kansalliseen omavaraisuuteen tähtäävään maatalouspolitiikkaan saattaa liittyä. Tutkielmassa tarkastellaan näitä allokaatiovaikutuksia hintasäännöstelyn ja kahdentyyppisen subventiojärjestelmän tilanteessa. Hyvinvoinnin muutosten osalta tukeudutaan kansantaloustieteestä tuttuun kuluttajan ylijäämän teoriaan.

Tulosten osalta todettakoon mm., että partiaalisen tasapainon mielessä tuotantoyksikköä kohden laskettu subventio on allokatiivisesti neutraali sïinä mielessä, että se ei muuta tuotantoyrityksen optimaalista kokoa. Sen sijaan yleisen tasapainon näkökulmasta yritysten lukumäärä kasvaa, mikä johtaa hintojen sopeutumiseen ja siten resurssien allokaation muuttumiseen ko. hyödykkeen ja muiden hyödykkeiden välillä. Tuotantoyksikköä kohden määritellyn subvention allokaatiovaikutukset ovat suuremmat. Partiaalisen tasapainon mallissa tuotantoyksikön optimikoko alenee subvention vaikutuksesta samalla kun yleisen tasapainon mielessä tuotantoyksiköiden lukumäärä kasvaa. Molemmissa tapauksissa hintasäännöstely yleisesti voimistaa allokaatiovinoutumaa.

Lopuksi on todettavissa, että omavaraisuustavoitteita ei luonnollisesti voida ajatella saavutettavan ilmaiseksi, vaan siitä on maksettava määrätty hinta. Tutkielmassa eritellään juuri tähän tavoitteeseen tähtäävän politiikan 
kustannuksia allokaation ja hyvinvoinnin kannalta. Sen sijaan on selvää, että tutkielma ei pysty vastaamaan kysymykseen, kuinka suuri hinta kansallisesta omavaraisuudesta korkeintaan kannattaisi maksaa.

\section{Kirjallisuusluettelo}

CAVES, R. E. and JONES, R. V. 1977. World Trade and Payments. An Introduction. Second Edition. 470 p. Little, Brown Company, Inc. Boston.

McKENZIE; G. W. 1979. Consumer's Surplus Without Apology: Comment. American Economic Review, 69: 465-468.

PRAT, J. W. 1964. Risk Aversion in the Small and in the Large. Econometrica 32: 122-136.

WALLACE, T. D. 1962. Measures of Social Costs of Agricultural Programs. Journal of Farm Economics, 46: 580-594.

WILliG, R. D. 1976. Consumer's Surplus Without Apology, American Economic Review, 66: 589-597.

WILliG, R. D. 1979. Concumer's Surplus Without Apology: Reply, American Economic Review, 69: $469-474$.

Ms received January 22, 1982. 